\title{
TESTIMONIAL EVIDENCE. PERSPECTIVES AND CONFLUENCES
}

\author{
Associate Professor Marius Neculcea PhD \\ „Vasile Goldiș” Western University of Arad
}

\section{Att. Bogdan Ionescu, Bar of Arad}

(Received March 2017; Accepted June 2017)

\begin{abstract}
The authors aim to "drill" into the complex issue of the testimonial evidence, through a fresher approach, thus being interested, besides the purely legal aspect, also in the historical, sociological and even psychological perspective.

Keywords: idem est non esse et non probari; testimonial evidence; testis unus, testis nullus; evolution Civil Law/Criminal Law; appreciation of testimonial evidence.
\end{abstract}

1. Basically, in all areas, evidence plays an essential role. Through it, widely expressed, the aim is to prove, to demonstrate something, with the goal of convincing about a truth. Thus, even a profane of the legal field will be able to be aware of the important role that evidence has in Law architecture. Common sense tells us that the lack of evidence must negatively impact the one that has the burden of proof and (due to one reason or another) cannot present the said evidence. The Roman legal experts transposed this idea into the saying idem est non esse et non probari - not proving the evidence equals to not being/means the same as if the evidence is non existent and not being proved. Thus, from a purely legal perspective, not proving a certain fact with legal means of evidence is the same as if the said fact did not exist [1]. We must underline that when talking about the object of evidence, we will consider the facts that the parties are presenting/ invoking, in opposition with the law, meaning with the legal norm that the judge must apply and which he is presumed to be aware of. (jura novit curia).

Concluding this introductive ideational frame, we are sending the following excellent explanations: the absence of factual evidence engages the absence of law. The existence of a right is, theoretically, independent from the evidence of facts that ground the claim. In practice however, there is no difference between having the right and not being able to bring the evidence of the fact which confers a legal prerogative. The evidence sets reality of a litigious fact [2].

2. Out of the evidence admitted both in the civil law, but in the criminal one as well, further we will stop (within the limits of article format, and also focusing only on some aspects of the matter - this being an extremely vast one) on the testimonial one, commonly known under the name of witness evidence. Logically 
and naturally, in opposition with the documentary evidence, the testimonial evidence should precede it (to be ahead), in treating it and in norming it in the procedural codices. The word preceded the writing, thus the testimonial evidence preceded the documentary evidence. Interestingly appears thus that the national legislator, in the New Criminal Procedure Code (brevitatis causa NCPP) observed this natural order of things, but has breached it in the New Civil Procedure Code (brevitatis causa NCPC), here where the documentary evidence "starts" from article 265 NCPC, and the testimonial evidence succeeds it (starting from article 309 NCPC).

3. Attention worthy is the evolution of the testimonial evidence in the civil matter. Thus, if the primitive legislation admitted it beyond any reserve, gradually, once the population was perfected and civilized, the testimonial evidence was excluded step by step, even only exceptionally [3] admissible in the present days. "The fall" of the testimonial evidence indubitably has its source in the literacy of populations, cumulated with the technological development and the accessibility (proximity) of the various great masses technologies [4].

4. We also notice that, in the evolution of the testimonial evidence, there was a time when it was imposed, with a great force, the dictum testis unus, testis nullus/unus testis non est audiendus, dictum that basically transmitted the idea that a sole witness is equal to no witness, one witness is no witness - thus even imposing (for proving the said fact) the requirement for a corroboration of at least two testimonial depositions. The herein discussed rule (expressed with the above given dictum) is usually attributed to a constitution of Constantine, from 334 (AD), who survived both the Code of Theodosius and that of Justinian [5].

5. In modern Romanian law, by principle, the judge is not compelled by the evoked rule, the assessment of evidence being free, left at his/her conviction. Nevertheless, it is absolutely remarkable how the dictum testis unus, testis nullus/ unus testis non est audiendus has managed to "survive" till nowadays, even if extremely disparate and in surprising prima facie matters.

Some examples:

$>$ In the (special) proceeding regarding the registration of rights acquired on the grounds of usucaption, the usucaption demand must include the surname, name and residence of at least 2 witnesses [see article 1051 paragraph (3) letter h) NCPC];

$>$ When celebrating a marriage, the consent of the future spouses is mandatorily given in the presence of 2 witnesses (see article 287 New Civil Code - brevitatis causa $\mathrm{NCC}$ ); 
When the administrator must perform an inventory, in certain circumstances, it must bear the signature of 2 witnesses [article 820 paragraph (5) NCC];

$>$ The will certification (in particular cases when the testator cannot sign) is made in the presence of 2 witnesses (see article 1045 NCC).

6. If in civil law the testimonial evidence has known a great decline, the things are not the same in criminal matters. Without doubt, the testimonial evidence, together with confession, is the most used evidence in criminal matters [6]. Nevertheless, the same authors want to further underline that the testimonial evidence is uncertain, and the fragility of the testimonial evidence is nowadays a matter on which is even ordinary to draw the judge's attention [7].

Despite this obvious (regarding the evidence fragility), the witness is, according to a famous, but also very beautiful saying of Jeremy Bentham, the eyes and ears of justice. The witness really plays a particularly special role in criminal proceedings. Notwithstanding, we do not want to take such an assertion for granted, axiomatically, but we wish to understand the mainsprings "behind" things, in order to then explain to other including why at a given time the testimonial evidence took such a different trajectory in civil matters compared to the one in criminal matters.

7. A possible explanation of the matter concerning us consists; let's call it such, in the specificity of facts in criminal matters. Regarding things very practically, it is unequivocally that in criminal matters we can only talk about facts provided (expressly) by the criminal law, meaning crimes - nulla poena sine lege/ nullum crimen sine lege. Withal, we cannot ignore (essentially) the different manner of perpetration/occurrence/committing of facts entering the area of civil law, from those from criminal matters. All these depend on the human nature. Fundamentally, a crime is aimed at being perpetrated in the greatest secrecy, hidden, secluded, isolated, far from the peoples' sight and perception (via the other senses), as "clean" as possible, in order not to leave traces, clues, all with the supreme purpose of not being caught, to get away without any sentence. Here is why a person aware of the perpetration is of such importance to criminal justice, being fully possible that based on his/her testimonial deposition (as starting point) to go further on a certain investigation trail, investigation where new means of evidence may be obtained, evidence which, corroborated, may lead to identifying the perpetrators and to drawing their criminal liability.

In contrast, in civil matters, facts are more visible, more public, persons are driven by other interests and reasons, aiming especially at pre-constituted evidence (and not their "removal"), not at all randomly the documentary evidence becoming here the most important evidence, witnesses being called in the civil trial only when the 
parties do not hold evidence based on documents/ scripts, or when the said evidence is inappropriate.

8. Getting back to the previously evoked matter, maybe the most difficult in the matter, namely of fragility, uncertainty, of a somehow uncertainty relevant to testimonial evidence. Man (due to the fact that only a human being may have the quality of witness, legally) indeed is an imperfect being. His/her senses may betray $\mathrm{him} / \mathrm{her}$, the passing of time affects his/her memory, may lie with great art and stratagem, is corruptible, is subject to blackmail, easily influenced, vindictive, avid for gain, malicious, or just naïve, timid, ingenuous or compassionate [8]. All these and many others may decisively affect the testimony exposed as a witness, thus flagrantly altering it from the purpose and finality aimed by the legislator, which is finding the truth.

On these coordinates, the main means for regulating the testimonial evidence in modern times is to control the manner in which the evidence is heard/administered and contested [9]. Withal, a multitude of leverages and mechanisms were imagined, which individually and/or cumulated are aimed in getting/determining the sincerity of the testimony, so the supreme desideratum of any justice - finding the truth. We state here either only the mandatory feature of religious or laic oath imposed to the witness, "the creation" of a deceitful testimony offence (perjury), measures for protecting the threatened, protected or vulnerable witnesses,, or facing witnesses who give contradictory statements.

9. We conclude our article with the issue of testimonial evidence assessment. Thus, if the NCPC provides a particular and express order on this issue [10], the NCPP is "poorer" in explanations, only offering us the wide general text of article 103, under the title "Evidence assessment" [11].

Regardless of these texts however, the reality is that the assessment of the testimonial evidence is a difficult task. This due to the fact that a truly professional magistrate must ask himself/herself if the said testimonial deposition was a sincere one and cumulatively answers this issue, then concretely grounding why he/she assumed and reclaimed it in the complete proving material, or why he/she dismissed it. It is true that the magistrate has a great assessing power on witnesses depositions, however this power should also be "moderated" by the coerciveness to clearly and precisely ground the chosen option. Otherwise, maybe the most fundamental and sacrosanct trial right would be infringed, namely the right to a fair trial (regarded as lato sensu).

10. In our opinion (somehow inevitably a general one referring to the complexity of the issue related to the assessment of the testimonial evidence) it is crucial to 
identify how the witness was made aware on those reported. Obviously, the eye witness, who directly found, ex propriis sensibus the said state of facts is the most valuable one from a proving point of view, but that does not automatically make him the most reliable. It must be also analysed which is the witness's relationship to the parties involved, if he/she is close to one of the parties, is a subordinate of one, has any interest in the cause (and if so, what is it), if he/she aims to get a personal gain (directly or indirectly) through the said deposition, or owes something to the party that proposed him/her. These are just some of the elements/clues that may outline the witness's degree of sincerity. Finally, the attentive examination, with the greatest thoroughness, of the testimonial deposition per se (per se) is essential in the magistrate's work to enforce justice. For example, the possible time miscorrelations from the testimony, the factual contradictions, the sophisticated statements (truth always had the "face" of simplicity and natural), a certain incoherence and inconsistency in the narrative line, unnatural discontinuities, the abundance and exactness of details for a certain far past fact and the incapacity to present some very recent aspects (without being able to justify/ explain such a difference and without being able to relate the past event to another event which should bring the first one into memory). Obviously also the direct perception of the magistrate related to the person's conduct at the time he/she is making the statement (for instance a state of restlessness, excitement, wonder or irritation when a certain question is addressed to him/her) may contribute in setting the witness "profile" - honest or insincere. Including this small conceptual frame shows us how important it is that the witness is heard directly by the trial court, and how useful it would be for the magistrates to be taught basic psychology notions (as science that studies human behaviour), but also that the access to the statute of judge should only occur after a certain age, after gathering a rich life but also professional experience (for instance as prosecutor, attorney, investigative body of the judicial police).

11. Further, at the end of our study, other doctrinaire opinions appear as useful to us, thus the reader being able to get a more complete image of the discussed issue:

$>$ Assessing the credibility of any testimonial assertion requires consideration of three attributes: veracity, objectivity, and observational sensitivity. The term veracity has caused many difficulties in studies of witness credibility (...). So, a person is being untruthful in testimony only if this person testifies against his/her beliefs. We must be sure that challenges to a witness's credibility are based on the correct forms of ancillary evidence. For example, evidence that a witness has poor eyesight is not a challenge to the witness's veracity (...). By definition, an objective observer is one who forms a belief based on evidence rather than on surmise/expectations, or on desire (...). So, we now come to the credibility 
attribute we have labeled observational sensitivity. There is much more to this attribute than just considering the adequacy of a witness's sensory systems: vision, hearing, touch, smell, and taste. Of course it is true that a person may be mistaken in testimony if his visual acuity was poor (...). But a witness having very acute sensory powers under normal circumstances may still obtain faulty sensory evidence. Much depends on a witness's general physical condition at the time of an observation. If the person was intoxicated, or under the influence of some narcotic or other chemical substance, we cannot expect this person to make full use of her sensory capabilities [12].

$>$ To test the credibility (...) is, to examine him minutely as to small matters, which have already been fully explained by previous, unsuspected witnesses, and on which there is no likelihood that he could think of framing a story, nor any probability that such story, if framed, would be consistent with the facts previously deposed to by unimpeachable witnesses. If what he says coincides with what has previously been established, in the seemingly trifling, but really important matters, the presumption is strong that he has also spoken truly in those more important points which directly concern the prisoner [13].

$>$ The assessment factors should not serve just as a guideline, thinks the judge Jean-Paul Aubin, from the Québec Court (...). In order to assess the evidence, the judge uses his/her sense of observation, his/her knowledge, his/her experience in matters of human relations and his/her logic, but also his/her sixth sense. A witness, wishing to be liable, once stated in front of judge Aubin: "What I stated is $100 \%$ true, I swear on my father's head". Intuition determined the judge to ask:

- Is your father alive or dead?

- I have never met my father.

The surprising answer placed a doubt in the judge's mind regarding the testimony veracity. Corneille wrote: "A liar is always generous with oaths". We might even add, as Margaret of Navarre that: forcing the oath creates certain doubts on the truth spoken [14].

$>$ Usually, the credibility of the witness is carefully considered. Generally, any witness can testify (...). The character of the witness, his or her interest in the outcome of the controversy, his or her independence from the parties, are all important factors in weighing witness testimonies. The quality of the testimony, including its potential in bringing information out of first-hand knowledge or in a hearsay mode, and its ability to corroborate other evidence coming from other witness testimonies or documents, or its contradiction with other testimonies and documents, are also factors to be taken into consideration in appreciating the weight of any given testimony. Generally, little weight is granted to testimonies made without basis of direct personal knowledge, or stated by (...) their employees, 
or by interested witnesses, unless other concordant statements or documentary evidence corroborate them [15].

\section{References}

1. T. Anderson, D. Schum, W. Twining, Analysis of Evidence, ed. 2, Cambridge University Press, 2005;

2. L. Baribeau, L'art d'apprécier les témoignages, Journal du Barreau, vol. 37, nr. 2/2005;

3. M. Franchimont, A. Jacobs, A. Masset, Manuel de procédure pénale, ed. 2, Larcier, 2006;

4. Th. Hoscheit, Chronique de droit judiciaire privé: Les témoins, Pas. t. 32;

5. John D. Jackson, Sarah J. Summers, The Internalisation of Criminal Evidence, Cambridge University Press, 2012;

6. M.G. Massé, Le Droit Commercial dans ses rapports avec le Droit Des Gens et Le Droit Civil, t. VI, Paris, 1847;

7. S. Menétrey, Procédure Civile Luxembourgeoise. Approche comparative, Larcier, 2016;

8. D. Mougenot, Droit des Obigations. La preuve, Larcier, 2002, p. 272;

9. Pierre Van Ommeslaghe, Traité de Droit Civil Belge. Les obligations, t. II, Bruylant, 2013;

10. Roscoe's Digest of the Law of evidence in Criminal Cases, ed. 5, London, 1861 ;

11. A. Sayed, Corruption in international Trade and Commercial Arbitration, Kluwer Law International, 2004, p. 96;

12. Theo. L. De Vinne, The Invention of Printing, New York, 1876;

13. A. Watson, Critical Studies in Ancient Law, Comparative Law and Legal History, Hart Publishing, 2004.

\section{Notes}

[1] We think a tone is imposed here, that is the saying idem est non esse et non probari aims solely the situation in which a right is being contested (so when a legal dispute exists), the saying thus having a limited effect and an effect which related to certain circumstances and people - in the same respect is also Pierre Van Ommeslaghe, Traité de Droit Civil Belge. Les obligations, t. II, Bruylant, 2013, no. 1624.

[2] In this respect, see S. Menétrey, Procédure Civile Luxembourgeoise. Approche comparative, Larcier, 2016, no. 451.

[3] It was elegantly underlined: the testimonial evidence and the evidence through presumptions are on another level than the documentary evidence (...). While the documentary evidence is always admissible in private law of obligations, the testimonial evidence and through presumptions is subject to certain strict admissibility rules. - D. Moungenot, Droit des Obigation, La prevue, Larcier, 2002, p. 272. 
[4] Related to these ideas (making a parallel with times when no advanced technology existed, or it is not accessible to the great population) we show that a "fairly written" Bible was sold in 1274, in England, for 50 "marks", equivalent of almost 33 pounds. At that time, a worker's wage was $1 \frac{1}{2}$ pence a day, and a sheep was bought for 1 schilling. - Theo. L. De Vinne, The Invention of Printing, New York, 1876, p. 169; to better understand these monetary units, we are showing that (approximately): 1 pound $=20$ schillings, 1 schilling $=$ 12 pence; so, basically, with the money needed to purchases the Bible, approximately 660 sheep could have been bought; It was beautifully asserted that: in the own nature of things and in the progress of enlightenment we find the cause of this progressive substitution of the testimonial evidence with the documentary evidence. At the origin of societies, when writing was not known, it was necessary to appeal to peoples' statements, who kept in memory the traces of facts and conventions. Later, when writing started to be introduced, but was still a science reserved to a small number, the oral testimony still prevailed. Then, when it was spread, the facility to set everything, entrusting everything to the written instrument, absolved the care of any memory entrusting, and the written instrument, which does not forget anything and is never wrong, ended in triumphing over peoples' statements (...) - M.G. Massé, Le Droit Commercial dans ses rapports avec le Droit Des Ges ei Le Droit Civil, t. VI, Paris, 1847, p. 176.

[5] In this respect, see A. Watson, Critical Studies in Ancient Law, Comparative Law and Legal History, Hart Publishing, 2004, p. 109; remarkably, this rule is also registered in the Deuteronom 19:15 - A single witness will not suffice against a human being, to prove an illegality or a certain sin; a fact may only be grounded on the testimony of two or three witnesses.

[6] In this respect, see M. Franchimont, A. Jacobs, A. Masset, Manuel de procedure pénale, $2^{\text {nd }}$ edition, Larcier, 2006, p. 1043.

[7] M. Franchimont, A. Jacobs, A. Masset, op. cit, p. 1043; in similar way, it was asserted that: the proof with witnesses was traditionally regarded with suspicion. Witnesses may lie, forget certain important aspects, may wrongly remember certain things, or purely may misinterpret a situation. Witnesses may be manipulated and their proof may depend on the questions addressed to them. - John D. Jackson, Sarah J. Summers, The Internalisation of Criminal Evidence, Cambridge University Press, 2012, p. 325.

[8] A foreign author also expresses here in a revealing manner: In the virtue of the fragility of human testimony, error being human, and considering that a witness deposition does not always constitute absolute truth, judges have a great assessment power on its value and incidence. It is generally acknowledged that the judge freely assess the degree of a witness's sincerity and preserved a sovereign power in assessing the force proving the testimonies produced before him/her in order to decide if it has the nature of allowing him/her to form a convincing opinion. - Th. Hoscheit, Chronique de droit judiciaire privé: Les témoins, Pas. t. 32, p. 19.

[9] In this respect, also see John D. Jackson, Sarah J. Summers, op. cit., p. 325.

[10] We refer to article 324, text which under the marginal title of "Assessment of the trial with witnesses" further holds: In assessing the witnesses statements, the court will take into account their sincerity and the circumstances in which they were made aware on the facts that are the object of the said statement. (personal translation) 


\section{JOURNAL OF LEGAL STUDIES}

"Vasile Goldiș" Western University of Arad

Neculcea, M., Ionescu, B. (2017)

Testimonial evidence. Perspectives and confluences

[11] Here we are only interested in paragraph (1) and paragraph (2) [and from the latter only in thesis I]. Concretely:

(1) Evidence do not have a value previously set by law and are subject to the free assessment of the legal bodies, following the assessment of all means of evidence administered in the cause.

(2) In making a decision on the existence of the offence and on the culpability of the defendant, the court decided in a grounded manner, with reference to all assessed means of evidence. (personal translation).

[12] T. Anderson, D. Schum, W. Twining, Analysis of Evidence, ed. 2, Cambridge University Press, 2005, p. 65 et seq.

[13] Roscoe's Digest of the Law of evidence in Criminal Cases, ed. 5, London, 1861, p. 134.

[14] For these very interesting references, see the article of attorney L. Baribeau, L'art d'apprécier les témoignages, in Journal du Barreau, vol. 37, no. 2/2005.

[15] A. Sayed, Corruption in international Trade and Commercial Arbitration, Kluwer Law International, 2004, p. 96. 